\title{
DETERMINATION OF DIPHENHYDRAMINE BY HPLC METHOD IN BIOLOGICAL LIQUIDS
}

\author{
O. Mamina, V. Kabachny, T. Tomarovska, N. Bondarenko
}

\begin{abstract}
The aim of the study was to develop an algorithm for directed analysis of diphenhydramine in biological extracts from urine and blood using a unified method of HPLC research.

Materials and methods. The extraction of diphenhydramine was carried out with chloroform at pH 9.0. The extracts were purified from impurities by a combination of TLC and extraction with hexane. TLC purification and identification of diphenhydramine were carried out under optimal conditions: organic solvents systems - chloroform-methanol (90:10); methanol; methanol-25\% solution of ammonium hydroxide (100:1.5) and chromatographic plates - Sorbfil PTLC-AF-A, Sorbfil PTLC-P-B-UV. For the detection of diphenhydramine, the most sensitive location reagents were used $-U V$ light $(\lambda=254 \mathrm{~nm})$ and Dragendorff reagent in the modification of Mounier.
\end{abstract}

HPLC analysis was carried out on a microcolumn liquid chromatograph "Milichrome A-02" in conditions: reversed-phase variant, column with non-polar sorbent Prontosil 120-5 $C_{18}$ AQ, $5 \mu \mathrm{m}$; mobile phase in the mode of linear gradient - from eluent A (5\% acetonitrile and $95 \%$ buffer solution) to eluent B (100\% acetonitrile) as during $40 \mathrm{~min}$. The flow rate of the mobile phase has been formed $100 \mu \mathrm{l} / \mathrm{min}$, injection volume $-4 \mu \mathrm{l}$. Multichannel detection of the substance was carried out using a UV spectrophotometer at 210, 220, 230, 240, 250, 260, 280 and $300 \mathrm{~nm}$; the optimal value of column temperature - 37-40 ${ }^{\circ} \mathrm{C}$ and pressure of pump 2.8-3.2 MPa.

Results and its discussion. Extraction, purification, identification and quantitative determination of diphenhydramine were carried out according to the developed methods. It is established that when isolating diphenhydramine from blood according to the developed methods it is possible to allocate 34.2-38.4\% of substance $(\bar{\varepsilon}= \pm 5.69 \%, R S D \bar{x}=2.04 \%)$ and from urine $-55.8-60.5 \%$ of substance $(\bar{\varepsilon}= \pm 3.91 \%, R S D \bar{x}=1.40 \%)$.

Conclusions. An algorithm has been developed for directed analysis of diphenhydramine in biological extracts from urine and blood using a unified HPLC method. Statistical processing of the experimental results indicates the reliability and reproducibility of the technique

Keywords: diphenhydramine hydrochloride, extraction with chloroform, analysis by HPLC method, blood, urine

Copyright (C) 2020, O. Mamina, V. Kabachny, T. Tomarovska, N. Bondarenko. This is an open access article under the CC BY license (http://creativecommons.org/licenses/by/4.0).

\section{Introduction}

Diphenhydramine hydrochloride (dimedrol) - 2diphenylmethoxy-N,N-dimethylethylamine hydrochloride - first generation of $\mathrm{H}_{1}$-histamine receptor blocker. The effect on the central nervous system occurs due to the blockade of $\mathrm{H}_{3}$-histamine receptors in the brain and inhibition of the central cholinergic structures. The drug has a pronounced antihistamine activity, reduces or prevents histamine-induced smooth muscle spasms, increasing capillary permeability, tissue edema, itching and hyperemia.

Diphenhydramine causes the effect of local anesthesia, blocks the cholinergic receptors of the ganglia, lowers blood pressure, has sedative, hypnotic, antiparkinsonian and antiemetic effects. The drug is used to treat anaphylactic shock, urticaria, hay fever, Quincke's edema, dermatoses, allergic eye diseases, allergic reactions associated with taking medications $[1,2]$.

Currently, diphenhydramine hydrochloride is widely used in various fields of medicine. So, Sawicka K. M. and co-authors presented data on the successful treatment of paroxysmal movement disorders in children with diphenhydramine due to anticholinergic activity and limited toxicity at low doses [3]. According to $\mathrm{Li} \mathrm{Y.Y.} \mathrm{and} \mathrm{co-authors} \mathrm{diphenhydramine} \mathrm{in} \mathrm{the}$ prophylactic process reduces bladder discomfort in patients in the postoperative period [4]. Pickett L.E. and coauthors found that the use of diphenhydramine is effective for patients with an allergy to lidocaine during skin surgical procedures [5].

According to the work of Drogovoz S. M. and coauthors the increased uncontrolled use of $\mathrm{H}_{1}$-histamine receptor blockers is also due to the multivectorial pharmacological effects, the ability to potentiate the effect of analgesics and alcohol on the central nervous system. The small latitude of the therapeutic action of antihistamines increases the risk of intoxication with an increase in the therapeutic dose by $3-5$ times, and the symptoms of poisoning can be delayed in time due to a decrease in the absorption rate of antihistamines, since they block the motility of the gastrointestinal tract, and also due to the relatively high affinity for transport proteins [6]. 
In case of an overdose, diphenhydramine hydrochloride causes respiratory depression and central nervous system depression, confusion, hyperkinesia, convulsions, delirium, tachycardia, arrhythmia [7]. Given the urgency of diphenhydramine poisoning, Varma A. and co-authors studies were carried out to remove patients from the state of intoxication, the influence of various factors on this process was studied [8]. Cherukuri S. V. and co-authors presented a case of severe overdose of diphenhydramine by a woman after taking $18 \mathrm{~g}$ (360 tablets of $50 \mathrm{mg}$ ) of the drug (coma of a patient with hemodynamic instability and hypotension), for the treatment of which lipid emulsion therapy was used [9].

Particular attention is paid to the mortality of children when taking anti-cold drugs, which contained diphenhydramine. The FDA has banned the use of these drugs in children under 6 years and restricted in children under 12 years. As a result of damage to the body, arrhythmia develops, which leads to cardiac arrest. Firstgeneration antihistamines are responsible for $8.3 \%$ of deaths from overdose poisoning in adults, according to U.S. toxicology services [10].

The detection and quantification of diphenhydramine hydrochloride in pharmaceuticals and biological matrices during treatment and after human death are based on the choice of highly sensitive and selective research methods, which is an urgent problem.

The most widely used method is high performance liquid chromatography (HPLC). The literature presents HPLC methods for the study of diphenhydramine using different conditions (variants of detection of the test substance, the use of isocratic and gradient modes of elution, the use of different composition of mobile phases, sorbents, buffer solutions), which are based on individual properties, but they do not take into account complex treatment of allergic diseases and intoxications with mixtures of different drugs.

Urine and blood, in which native substances and their metabolites are localized, are characterized by significant informativeness in conducting research in biological matrices. An actual problem is the development of an algorithm for directed analysis of diphenhydramine in urine and blood using a unified HPLC method of analysis and the creation of a database of identification parameters, quantification of the above method of firstgeneration antihistamines.

Zagorodniy S. L. and co-authors developed a method of HPLC analysis of diphenhydramine in tablets [11]. Chromatography was performed in reversed-phase variant using a $4.0 \mathrm{~mm} \mathrm{x} 150.0 \mathrm{~mm}$ column with Hypersil Gold sorbent, $5 \mu \mathrm{m}$. Elution was conducted in isocratic mode using a mobile phase - phosphate buffer solution - acetonitrile (80:20). Analysis of diphenhydramine by UV spectrophotometric detector was performed only at one wavelength $-254 \mathrm{~nm}$.

Zhilyakova E.T. and co-authors for the identification and determination of miramistin and diphenhydramine in the joint presence of eye drops in a viscous dispersion medium, a selective HPLC method was developed [12]. According to this technique, chromatography was carried out in a reversed-phase version using a $4.0 \mathrm{~mm} \times 250.0 \mathrm{~mm}$ steel column filled with a $5 \mu \mathrm{m}$ Spherisorb $\mathrm{CN}$ sorbent. Elution was carried out in an isocratic mode using a mobile phase - phosphate buffer solution pH 2.5 - methanol (10:90). The analysis of substances with a UV spectrophotometric detector was carried out only at one wavelength $-262 \mathrm{~nm}$.

Grigoriev A. M. and co-authors developed HPLCmethod for determining of the metabolites of diphenhydramine in urine [13]. According to this technique, chromatography was carried out in a reversed-phase variant using a steel column $4.6 \mathrm{~mm} \times 150.0 \mathrm{~mm}$ filled with an Eclipse XDB-C $18,5 \mu \mathrm{m}$ sorbent. Elution was carried out in a gradient mode using eluent $\mathrm{A}$ (phosphate buffer $\mathrm{pH}$ 3.0) and eluent $\mathrm{B}$ (acetonitrile). Linear gradient $-A: B=9: 1$ to $3: 7$. The analysis of substances with a diode-array detector was carried out only at two wavelengths -220 and $360 \mathrm{~nm}$.

Gelotte C. K. and co-authors used the HPLC method to study the pharmacokinetics of diphenhydramine in blood plasma after a single oral dose in children aged 2 to 17 years according to a dosing regimen based on weight and age with a large number of levels [14]. Chromatography was carried out in a reversed-phase variant with the detection of substances by tandem mass spectrometry. The analysis was performed on a Discovery ${ }^{\circledR}$ RP Amide C16 column, $10 \mathrm{~cm}$ x $3 \mathrm{~mm}, 5 \mu \mathrm{m}$. Elution was performed in an isocratic mode using $20 \%$ eluent A (acetate buffer pH 3.0) and $80 \%$ eluent B (acetonitrile).

The disadvantages of the above HPLC methods are the use of an isocratic elution mode, which limits the possibility of all sample components leaving the column in the form of narrow zones and efficient separation of drug mixtures. Detection at one or two wavelengths reduces the reliability of the results obtained in the identification, since it allows to use only the retention parameters. HPLC methods for the analysis of diphenhydramine have limitations in their application to the study of mixtures with other drugs.

Modern HPLC methods of diphenhydramine analysis indicate the absence of systematic studies, which does not allow the selection of optimal conditions for drug analysis in biological objects and pharmaceuticals.

The aim of the study was to develop an algorithm for directed analysis of diphenhydramine in biological extracts from urine and blood using a unified method of HPLC research.

\section{Planning (methodology) of research}

The creation of databases based on the results of express and cost-effective methods for analysis of biological fluids for the presence of drugs, which are based on unified methods of isolation, purification, identification and quantitative determination, is an important task of modern analytical services for the organization and monitoring of the effectiveness of treatment of the population and diagnosis of population intoxication with drugs.

The previously developed algorithms for the analysis of diphenhydramine in blood and urine $[15,16]$ were based on the use of various extractants, complex in composition (for example, extraction from blood with a mixture of solvents - n-hexane-dichloromethane-isopropanol $(60: 40: 2)$ at $\mathrm{pH} 9.5$ or selected taking into account the individual properties of the drug (for example, extraction 
from urine with a mixture of solvents - chloroformisobutanol (6:1) at pH 8.5. For HPLC and GC analysis of diphenhydramine, various conditions were also used (sorbents, eluents, temperature, pressure, mobile phase feed rate). The results obtained were different $(68.3 \%$ and $90.2 \%$ ) and were not characterized by reliability.

The presented study was distinguished by the use of unified methods and included the following stages: carrying out the extraction of diphenhydramine according to the unified method of isolation of organic substances of the basic character from biological objects, selection of optimal conditions for TLC purification and identification of diphenhydramine in biogenic extracts (thin layers of sorbents, organic solvents systems, substance detection means); use of the unified HPLC method of identification and quantification of diphenhydramine in biogenic extracts from urine and blood according to the developed algorithm of the directed analysis in biological extracts with application of the unified HPLC technique.

\section{Materials and methods}

Diphenhydramine hydrochloride was isolated from «Dimedrol» tablets (10 pcs) $50 \mathrm{mg}$ (Darnitsa, Closed JointStock Company, Kyiv, Ukraine) as follows: the number of tablets, which contained $300 \mathrm{mg}$, were transferred to the porcelain mortar and were triturated to a homogeneous state. $100.0 \mathrm{ml}$ of methanol was added to the mixture and mixed thoroughly. The resulting mixture was filtered through a paper filter in porcelain cup and evaporated in water bath at a temperature not higher than $40^{\circ} \mathrm{C}$ to remove the organic solvent; the residue was dried.

The purity of the substances was tested by TLC and UV spectroscopy and the quality assurance was established in accordance with the requirements of the pharmacopoeial article [17].

Organic solvents corresponded to the qualification of "PFA": chloroform, methanol, hexane (SigmaAldrich, USA). Reagents corresponded to the qualification of "PFA": $10 \%$ solution of acid trichloroacetic, $25 \%$ solution of ammonium hydroxide, 0.1 M solution of sodium hydroxide (Chimmed, Moscow, Russia).

$0.1000 \mathrm{~g}$ of test substance was added to a $100.0 \mathrm{ml}$ volumetric flask, dissolved in water and the volume of the solution was adjusted to the mark with solvent (standard solution, concentration $1000.0 \mu \mathrm{g} / \mathrm{ml}$ ).

According to the algorithm for the study of biological objects for the presence of drugs, the following steps were performed: isolation of the substance from the biological object, purification from nutrients, identification and quantification. The presence of impurities of organic origin (steroids, pigments, peptides, low molecular weight products of amino acid metabolism - amines, urea, carboxylic acids) in extracts from biological material reduced the objectivity of the results obtained in the quantitative determination of substances by HPLC method. Purification of extracts from co-extractive compounds was performed by combining TLC and hexane extraction.

Model mixtures of blood and urine with diphenhydramine were used for the studies, taking into account the lethal concentrations of the drug in the blood $(19.7-31.0 \mu \mathrm{g} / \mathrm{ml})$ and urine $(37.6-40.0 \mu \mathrm{g} / \mathrm{ml})$ [18]. To do this, $1000.0 \mu \mathrm{g}$ of diphenhydramine hydrochloride was added to $10 \mathrm{ml}$ of the appropriate biological fluid using an aqueous solution of the drug substance, which contained $1000.0 \mu \mathrm{g} / \mathrm{ml}$, as well as control samples. Samples were left for $24 \mathrm{~h}$ at room temperature. A day later, studies were performed according to the developed extraction techniques.

Methods of isolation of diphenhydramine from blood and urine and extract purification by hexane. To $10.0 \mathrm{ml}$ of a model mixture of blood or urine with diphenhydramine hydrochloride, $5.0 \mathrm{ml}$ of $10 \%$ solution of acid trichloroacetic was added for breaking bonds with proteins, mixed and checked with a universal indicator $\mathrm{pH}$ of the mixture $2.0-2.5$, left for $2 \mathrm{~h}$ with constant stirring at room temperature.

The mixture was centrifuged at 3000-5000 rpm for $10 \mathrm{~min}$, the the liquid over the precipitate was separated. Lipid impurities were extracted three times with hexane in portions of $5 \mathrm{ml}$. Hexane phases were not investigated.

The aqueous layer was alkalinized with a $0.1 \mathrm{M}$ solution of sodium hydroxide to $\mathrm{pH} 9.0$ and the diphenhydramine-base was extracted twice with chloroform in portions of $10.0 \mathrm{ml}$ followed by centrifugation at $3000-5000 \mathrm{rpm}$ for $10 \mathrm{~min}$ for the destruction of waterchloroform emulsions. Chloroform extracts were combined and filtered through a paper filter ("red tape") with $1.0 \mathrm{~g}$ sodium sulphate anhydrous, TLC-purification of the extracts was performed.

Methods of TLC purification of biogenic extracts. The purified chloroform solutions were evaporated at room temperature to dryness, which was dissolved in $2.0-3.0 \mathrm{ml}$ of methanol, then quantitatively transferred to a volumetric flask with a capacity of $5.0 \mathrm{ml}$, brought to the mark with methanol.

TLC purification was performed under conditions chromatographic plates Sorbfil PTLC-AF-A, system of organic solvents - chloroform-methanol (90:10), $R_{\text {fiphenhydramine }}=0.52 \pm 0.03$, impurities are located at the start line or at the finish line. Detection of diphenhydramine was performed under uniform conditions using the most sensitive developers - UV light $(\lambda=254 \mathrm{~nm})$ - purple color of the spots, sensitivity $-0.3-0.5 \mu \mathrm{g}$ in the sample, Dragendorff reagent in the modification of Mounier - orange color of the spots, sensitivity of the developer $-1.0-3.0 \mu \mathrm{g}$ of the substance in the sample.

To confirm the presence of diphenhydramine in biogenic extracts, the following conditions were used: organic solvent systems: methanol, $R_{\text {fiphenhydramine }}=0.56 \pm 0.03$ (Sorbfil PTLC-AF-A); methanol-25\% solution of ammonium hydroxide (100:1.5) $R_{f \text { diphenhydramine }}=0.55 \pm 0.03 \quad$ (Sorbfil PTLC-AF-A), $R_{f \text { diphenhydramine }}=0.55 \pm 0.03 \quad$ (Sorbfil PTLC-P-B-UV) [19].

TLC purification of diphenhydramine in the extracts was performed according to the following method: $1.0 \mathrm{ml}$ of methanolic solution of diphenhydramine after extraction purification, evaporated to $0.3-0.5 \mathrm{ml}$. At the starting line of the chromatographic plate at a distance of $1-2 \mathrm{~cm}$ from the edge to the point was applied using a calibrated capillary witness $-0.01 \%$ methanol solution of diphenhydramine. At a distance of $1-2 \mathrm{~cm}$ from the witness was applied an extract from the control 
sample, the diameter of the stain should not exceed 0.5 $\mathrm{cm}$. Methanol solution of diphenhydramine after extraction purification was applied in the form of a strip 1.0$1.5 \mathrm{~cm}$ long.

The chromatographic plate was placed in a chromatography chamber, which was a glass vessel with a ground lid with a volume of $500 \mathrm{~cm}^{3}$, into which a system of solvents for chromatography $(50 \mathrm{ml})$ was introduced, the chamber was carefully closed, followed by solvent vapor saturation for at least 30-60 minutes. The length of the mobile phase front was $7 \mathrm{~cm}$. Chromatography was completed when the solvent reached the finish line. The chromatographic plate was dried at room temperature. The part of chromatographic plate with localized the witness and control sample extracts was developed using UV light and Dragendorff reagent in the Mounier modification.

At the level of the spot of standard methanol $0.01 \%$ solution of diphenhydramine from the part of the plate that was not treated with the developer, removed a layer of sorbent with an area of $4-5 \mathrm{~cm}^{2}$, transferred to the filter. The substance was eluted three times with methanol of $5.0 \mathrm{ml}$ and the resulting solution was filtered through a filter ("red tape").

The resulting solutions were evaporated at room temperature to dryness, which was dissolved in 2.0$3.0 \mathrm{ml}$ of methanol, and then quantitatively transferred to a volumetric flask with a capacity of $5.0 \mathrm{ml}$, brought to the mark with methanol.

Methods of research of diphenhydramine by HPLC method. Chromatographic analysis was carried out on a microcolumn liquid chromatograph "Milichrome A-02" (EkoNova, Closed Joint-Stock Company, Novosibirsk, Russia) according to the unified HPLC method developed by Baram G. Y. [20]: reversed-phase variant with using of metal column with non-polar absorbent Prontosil $120-5 \mathrm{C}_{18}$ AQ, $5 \mu \mathrm{m}$; mobile phase in the mode of linear gradient - from eluent A (5\% acetonitrile and $95 \%$ buffer solution - $0.2 \mathrm{M}$ solution of lithium perchlorate in $0.005 \mathrm{M}$ solution acid perchloric) to eluent $\mathrm{B}$ (100\% acetonitrile) as during $40 \mathrm{~min}$. Regeneration of column has been conducted during 2 min with mixture of solvents; the flow rate of the mobile phase has been formed $100 \mu \mathrm{l} / \mathrm{min}$, injection volume $-4 \mu \mathrm{l}$.

Multichannel detection of the substance was carried out using a two-beam multi-wave UV spectrophotometer at 8 wavelengths of 210, 220, 230, 240, 250, 260, 280 and $300 \mathrm{~nm}$; the optimal value of column temperature $-37-40{ }^{\circ} \mathrm{C}$ and pressure of pump $-2.8-3.2 \mathrm{MPa}$.

\section{Results}

Identification of diphenhydramine was performed by retention parameters and spectral ratios. It was found that the absolute retention time of diphenhydramine was $20.28 \pm 0.02 \mathrm{~min}$, the absolute retention volume was $2028.32 \pm 0.32 \mu \mathrm{l}$. To obtain reliable identification results, the spectral ratios of the optical density values at wavelengths from 220 to $280 \mathrm{~nm}$ to the optical density values at $210 \mathrm{~nm}$ were determined $-0.713 \pm 0.006 ; 0.305 \pm 0.005$;
$0.034 \pm 0.005 ; \quad 0.023 \pm 0.004 ; 0.029 \pm 0.003 ; 0.001 \pm 0.006 ;$ $0.001 \pm 0.007$.

The concentration of diphenhydramine in methanol solution $(\mathrm{C}, \mu \mathrm{g} / \mathrm{ml})$, which was obtained after purification of biogenic extracts by TLC and extraction methods, was calculated using a calibration graph or the equation of the line corresponding to the calibration graph.

The linearity of the calibration graph was observed in the concentration ranges of $10.0-200.0 \mu \mathrm{g} / \mathrm{ml}$, which corresponded to the content of diphenhydramine in the sample $(4 \mu \mathrm{l})$ from $40.0 \mathrm{ng}$ to $800.0 \mathrm{ng}$. The lower limit of determination of diphenhydramine by HPLC was $10.0 \mu \mathrm{g} / \mathrm{ml}$ (40.0 $\mathrm{ng}$ in the sample).

The equation of the linear dependence of the area of diphenhydramine peaks $\left(\mathrm{S}, \mathrm{mm}^{2}\right)$ on its concentration $(\mathrm{C}, \mu \mathrm{g} / \mathrm{ml})$ had the form: $\mathrm{S}=0.60 \cdot 10^{-3} \mathrm{C}+0.64 \cdot 10^{-3}$. The correlation coefficient was 0.9989 [21].

The degree of isolation of diphenhydramine from biological objects was calculated by the formula:

$$
C_{x}=\frac{C \cdot V_{1} \cdot V_{3} \cdot k \cdot 100}{a \cdot V_{2}},
$$

where $\mathrm{C}_{\mathrm{x}, \%}$ - mass fraction of diphenhydramine in $10 \mathrm{ml}$ of blood or urine, in \%;

$\mathrm{V}_{1}$ - volume of a volumetric flask with methanol extract of the substance from biological fluids after extract purification $(5 \mathrm{ml})$;

$\mathrm{V}_{2}$ - volume of methanol extract of the substance from biological fluids, taken for TLC purification (1 ml);

$\mathrm{V}_{3}$ - volume of the volumetric flask with the extract after TLC purification using methanol (5 ml);

$\mathrm{k}$ - coefficient of recount, which is equal to the ratio of molecular weights of salt / base;

a - weight of the sample of diphenhydramine hydrochloride, which is made in $10.0 \mathrm{ml}$ of blood or urine $(1000.0 \mu \mathrm{g})$.

The results of the study are shown in Table 1 .

According to the results of research it was established that when isolating diphenhydramine from blood according to the developed methods it is possible to allocate $34.2-38.4 \%$ of substance

$$
(\bar{\varepsilon}= \pm 5.69 \%, R S D \bar{x}=2.04 \%)
$$

and from urine $-55.8-60.5 \%$ of substance

$$
(\bar{\varepsilon}= \pm 3.91 \%, R S D \bar{x}=1.40 \%)
$$

The limit of quantitative determination of diphenhydramine in biological fluids by HPLC was $-0.5-$ $0.7 \mu \mathrm{g}$ in the sample.

According to the results of HPLC and TLC studies, an algorithm for directed analysis of biological fluids for diphenhydramine was developed (Table 2). 
The results of HPLC analysis of diphenhydramine in blood and urine extracts $(n=5, P=95 \%)$

\begin{tabular}{|c|c|c|c|c|c|c|c|c|}
\hline \multirow{2}{*}{$\begin{array}{l}\text { The value of the area of the peaks } S \text {, } \\
\qquad \mathrm{mm}^{2}\end{array}$} & \multicolumn{2}{|c|}{$\begin{array}{c}\text { Diphenhydramine was } \\
\text { isolated }\end{array}$} & \multicolumn{6}{|c|}{ Metrological characteristics, $\%$} \\
\hline & $\mu \mathrm{g}$ & $\%$ & $\bar{X}$ & $\mathrm{~S}$ & $R S D \bar{x}$ & $S \bar{x}$ & $\Delta \bar{x}$ & $\bar{\varepsilon}$ \\
\hline \multicolumn{9}{|c|}{ Blood } \\
\hline $\begin{array}{l}0.0088 \\
0.0092 \\
0.0094 \\
0.0097 \\
0.0099 \\
\end{array}$ & $\begin{array}{l}13.68 \\
14.20 \\
14.68 \\
15.04 \\
15.36 \\
\end{array}$ & $\begin{array}{l}34.2 \\
35.5 \\
36.7 \\
37.6 \\
38.4 \\
\end{array}$ & 36.48 & 1.67 & 2.04 & 0.75 & 2.08 & 5.69 \\
\hline \multicolumn{9}{|c|}{ Urine } \\
\hline $\begin{array}{l}0.0140 \\
0.0143 \\
0.0147 \\
0.0149 \\
0.0152\end{array}$ & $\begin{array}{l}22.32 \\
22.84 \\
23.44 \\
23.68 \\
24.20\end{array}$ & $\begin{array}{l}55.8 \\
57.1 \\
58.6 \\
59.2 \\
60.5\end{array}$ & 58.24 & 1.83 & 1.40 & 0.82 & 2.28 & 3.91 \\
\hline
\end{tabular}

Algorithm for directed analysis of diphenhydramine in biological fluids

\begin{tabular}{|c|c|}
\hline Stage of the algorithm & Conditions of performance \\
\hline $\begin{array}{l}\text { Destruction binding of diphenhydramine } \\
\text { to proteins }\end{array}$ & $\begin{array}{l}\text { To } 10.0 \mathrm{ml} \text { of a model mixture of blood or urine with diphenhydramine } \\
\text { hydrochloride, } 5.0 \mathrm{ml} \text { of } 10 \% \text { solution of acid trichloroacetic was added, } \\
\text { mixed and checked with a universal indicator } \mathrm{pH} \text { of the mixture } 2.0-2.5 \text {, } \\
\text { left for } 2 \mathrm{~h} \text { with constant stirring at room temperature. }\end{array}$ \\
\hline Extraction purification by hexane & $\begin{array}{l}\text { The mixture was centrifuged at } 3000-5000 \mathrm{rpm} \text { for } 10 \mathrm{~min} \text {, the the liquid } \\
\text { over the precipitate was separated. Lipid impurities were extracted three } \\
\text { times with hexane in portions of } 5 \mathrm{ml} \text {. Hexane phases were not investi- } \\
\text { gated. }\end{array}$ \\
\hline $\begin{array}{l}\text { Chloroform extraction of diphenhydra- } \\
\text { mine base }\end{array}$ & $\begin{array}{l}\text { The aqueous layer was alkalinized with a } 0.1 \mathrm{M} \text { solution of sodium hy- } \\
\text { droxide to } \mathrm{pH} 9.0 \text { and the diphenhydramine-base was extracted twice } \\
\text { with chloroform in portions of } 10.0 \mathrm{ml} \text { followed by centrifugation at } \\
3000-5000 \mathrm{rpm} \text { for } 10 \mathrm{~min} \text { for the destruction of water-chloroform } \\
\text { emulsions. }\end{array}$ \\
\hline $\begin{array}{l}\text { TLC-purification and preliminary } \\
\text { identification of diphenhydramine in ex- } \\
\text { tracts }\end{array}$ & $\begin{array}{l}\text { System of organic solvents }- \text { chloroform }- \text { methanol }(90: 10) \text {, developers - } \\
\text { UV light, Dragendorff reagent modified by Munier, } \\
R_{\text {fiphenhydramine }}=0.52 \pm 0.03 \text { (Sorbfil PTLC-AF-A). }\end{array}$ \\
\hline $\begin{array}{l}\text { Confirming TLC-identification of } \\
\text { diphenhydramine in extracts }\end{array}$ & $\begin{array}{l}\text { Methanol }-R_{f}=0.56 \pm 0.03 \text { (Sorbfil PTLC-AF-A); methanol }-25 \% \text { solu- } \\
\text { tion of ammonium hydroxide }(100: 1.5)-R_{f}=0.55 \pm 0.03 \text { (Sorbfil PTLC- } \\
\text { AF-A); } R_{f}=0.55 \pm 0.03 \text { (Sorbfil PTLC-P-B-UV). }\end{array}$ \\
\hline $\begin{array}{l}\text { Confirming HPLC-identification of } \\
\text { diphenhydramine in extracts }\end{array}$ & $\begin{array}{l}\text { Diphenhydramine was identified with the retention time of } 20.28 \pm 0.02 \\
\text { min; retention volume } 2028.32 \pm 0.32 \mu \mathrm{l} \text {; spectral relations: } 0.713 ; 0.305 \text {; } \\
0.034 ; 0.023 ; 0.029 ; 0.001 ; 0.001 \text {. }\end{array}$ \\
\hline $\begin{array}{l}\text { Quantitative determination of di- } \\
\text { phenhydramine in extracts by HPLC- } \\
\text { method }\end{array}$ & $\begin{array}{l}\text { The range of linearity of the calibration graph was } 10.0-200.0 \mu \mathrm{g} / \mathrm{ml} \text {, } \\
\text { which corresponds to the content of diphenhydramine in the sample from } \\
40.0 \mathrm{ng} \text { to } 800.0 \mathrm{ng} \text {, respectively. To determine the amount of diphenhy- } \\
\text { dramine, the equation was used } \mathrm{S}=0.60 \cdot 10^{-3} \mathrm{C}+0.64 \cdot 10^{-3} \text {, the correlation } \\
\text { coefficient was equal } 0.9998 \text {. }\end{array}$ \\
\hline
\end{tabular}

\section{Discussion}

The developed algorithm for the analysis of diphenhydramine in blood and urine had advantages over the previously indicated methods $[15,16]$. The analysis was differed by its economy and universality for basic substances - the extraction of diphenhydramine from blood and urine was carried out with chloroform at $\mathrm{pH} 9.0$.

At the stage of isolation of diphenhydramine, the destruction of bonds with proteins in an acidic medium was carried out, followed by purification of the extracts from impurities by different methods - extraction with hexane and TLC. The high degree of purification of extracts from impurities made it possible to obtain reliable and reproducible results according to metrological characteristics. It was found that the relative uncertainty of the average result in the analysis of diphenhydramine in biological fluids was 3.91-5.69\%, the relative standard deviation of the average result was within 1.40-2.04\%.

Algorithms of the analysis of diphenhydramine using solvents -n-hexane-dichloromethane-isopropanol (60:40:2) and chloroform-isobutanol (6:1) did not in- 
clude multi-stage cleaning. So, when analyzing blood by HPLC method, only the guard column was used, which gave a significant scatter of the isolation results $58.3 \%, 70.1 \%, 77.0 \%[15,16]$.

The advantage of using a unified HPLC technique was the ability to identify diphenhydramine by retention parameters and spectral ratios, which made the results accurate, reliable and reproducible. The use of a linear gradient elution mode made it possible to obtain symmetric, sharp in shape chromatographic peaks (the symmetry coefficient of the peaks did not exceed 2-2.5) and to carry out their reliable processing. The results of identification and quantification by HPLC were calculated using a computer program "MultiChrome" (CJSC “Ampersend", Moscow, Russia), which was included in the chromatograph.

The disadvantages of the developed analysis were the low degree of extraction of diphenhydramine - from blood $34.2-38.4 \%$ and from urine $-55.8-60.5 \%$ of the substance compared with the results given in the literature $-68.3 \%$ from blood and $90.2 \%$ from urine $[15,16]$. These results are due to the lower extracting power of chloroform in comparison with mixtures of solvents with different polarities; losses during multi-stage purification of extracts from impurities. At the same time, the high degree of extraction of diphenhydramine from biological fluids, according to the literature data, could be due to the lack of effective purification, the influence of biogenic impurities, and getting false positive results.

Study limitations. In the course of our study, there were difficulties in providing the experiment with reagents, solvents and modern chromatographic equipment.

Prospects for further research. Chromatographic techniques can be recommended for implementation in practice of the Bureau of Forensic Medical Examination, poison control centers, clinical laboratories regarding the study of medicinal substances in biological objects.

\section{Conclusions}

Diphenhydramine was extracted with chloroform at $\mathrm{pH} 9.0$ from blood and urine. Purification of extracts from co-extractive compounds was performed by combining TLC and extraction with hexane. It is established that when isolating diphenhydramine from blood according to the developed methods it is possible to allocate 34.2-38.4 \% of substance $(\bar{\varepsilon}= \pm 5.69 \%, R S D \bar{x}=2.04 \%)$ and from urine -55.8 $60.5 \%$ of substance $(\bar{\varepsilon}= \pm 3.91 \%, R S D \bar{x}=1.40 \%)$.

The method of TLC purification and identification of diphenhydramine in biogenic extracts was tested under optimal conditions: system of organic solvents - chloroform - methanol (90:10), location reagents - UV light, Dragendorff reagent in the Mounier modification, $R_{\text {fdiphenhydramine }}=0.52 \pm 0.03 \quad$ (Sorbfil PTLC-AF-A). To confirm the presence of diphenhydramine in biogenic extracts, the following chromatographic conditions were used: organic solvents systems - methanol, $R_{\text {fdiphenhydramine }}=0.56 \pm 0.03$ (Sorbfil PTLC-AF-A); methanol-25\% solution of ammonium hydroxide (100:1.5) $R_{f \text { diphenhydramine }}=0.55 \pm 0.03 \quad$ (Sorbfil PTLC-AF-A), $R_{f \text { diphenhydramine }}=0.55 \pm 0.03$ (Sorbfil PTLC-P-B-UV).

The unified HPLC method for identification and quantification of diphenhydramine was tested in biogenic extracts from urine and blood according to the developed algorithm of directed analysis. It was found that diphenhydramine can be identified by retention time $20.28 \pm 0.02 \mathrm{~min}$; retention volume $2028.32 \pm 0.32 \mu \mathrm{l}$; spectral ratios $-0.713 ; 0.305 ; 0.034 ; 0.023 ; 0.029 ; 0.001$; 0.001 . Equation was used to determine the diphenhydramine content $\mathrm{S}=0.60 \cdot 10^{-3} \mathrm{C}+0.64 \cdot 10^{-3}$; the correlation coefficient was equal to 0.9989 .

Chromatographic techniques can be recommended for implementation in practice of the Bureau of Forensic Medical Examination, poison control centers, clinical laboratories regarding the study of medicinal substances in biological objects.

\section{Conflict of interests}

The authors declare that they have no conflicts of interest.

\section{References}

1. Mashkovskii, M. D. (2012). Lekarstvennye sredstva. Moscow: Novaia Volna, 1216.

2. Luss, L. V. (2016). Choice of an antihistamine administration route in the treatment of allergic diseases. Terapevticheskii Arkhiv, 88 (3), 93-95. doi: http://doi.org/10.17116/terarkh201688393-95

3. Sawicka, K. M., Goez, H., Huntsman, R. J. (2016). Successful Treatment of Paroxysmal Movement Disorders of Infancy With Dimenhydrinate and Diphenhydramine. Pediatric Neurology, 56, 72-75. doi: http://doi.org/10.1016/j.pediatrneurol.2015.10.019

4. Li, Y.-Y., Zeng, Y.-S., Chen, J.-Y., Wang, K.-F., Hsing, C.-H., Wu, W.-J. et. al. (2019). Prophylactic diphenhydramine attenuates postoperative catheter-related bladder discomfort in patients undergoing gynecologic laparoscopic surgery: a randomized double-blind clinical study. Journal of Anesthesia, 34 (2), 232-237. doi: http://doi.org/10.1007/s00540-019-02724-3

5. Pickett, L. E., Macdonald, J. (2016). Injectable Diphenhydramine Used as Anaesthetic for Wide Local Excision With Flap Closure. Journal of Cutaneous Medicine and Surgery, 21 (3), 256-257. doi: http://doi.org/10.1177/1203475416681760

6. Drogovoz, S. M., Lukianchuk, V. D., SHerman, B. S., Kononenko A. V. (2012). Toksicheskie effekty blokatorov N1 gistaminovykh retseptorov i mekhanizmy ikh formirovaniia. Sovremennye problemy toksikologii, 3-4, 58-59.

7. Thomas, S. H. L. (2012). Antihistamine poisoning. Medicine, 40 (3), 109-110. doi: http://doi.org/10.1016/j.mpmed.2011.12.012

8. Varma, A., Ford, L., Patel, N., Vale, J. A. (2017). Elimination half-life of diphenhydramine in overdose. Clinical Toxicology, 55 (6), 615-616. doi: http://doi.org/10.1080/15563650.2017.1296153

9. Cherukuri, S. V., Purvis, A. W., Tosto, S. T., Velayati, A. (2019). IV Lipid Emulsion Infusion in the Treatment of Severe Diphenhydramine Overdose. American Journal of Case Reports, 20, 758-763. doi: http://doi.org/10.12659/ajcr.912523

10. Namazova-Baranova, L. S. (2009). Smertnost ot antigistaminnykh preparatov pervogo pokoleniia. Pozitsiia reguliatornykh organov. Pozitsiia vracha-pediatra. Pediatricheskaia farmakologiia, 6 (3), 52.

11. Zagorodniy, S. L., Vasyuk, S. O. (2015). Validation of quantitative determination methods of diphenhyramine tablets by high performance liquid chromatography. Zaporozhye Medical Journal, 2 (89), 89-92. doi: http://doi.org/10.14739/23101210.2015.2.42122 
12. Zhiliakova, E. T., Zinchenko A. A., Novikov, O. O., Popov, N. N. (2015). Razrabotka metodiki opredeleniia miramistina i dimedrola v novykh prolongirovannykh glaznykh kapliakh dlia lecheniia bakterialnykh koniuktivitov. Nauchnye vedomosti Belgorodskogo gosudarstvennogo universiteta. Seriia: Meditsina. Farmatsiia, 30 (10), 211-217.

13. Grigorev, A. M., Mashkova, I. V., Rudakova, L. V. (2008). Opredelenie metabolitov dimedrola metodami GKH-MS i VEZHKH v moche. Sorbtsionnye i khromatograficheskie protsessy, 8 (1), 134-140.

14. Gelotte, C. K., Zimmerman, B. A., Thompson, G. A. (2017). Single-Dose Pharmacokinetic Study of Diphenhydramine $\mathrm{HCl}$ in Children and Adolescents. Clinical Pharmacology in Drug Development, 7 (4), 400-407. doi: http://doi.org/10.1002/cpdd.391

15. Krupina, N. A., Krasnova, R. R., Pashovkina, R. N. (2005). Khimiko-toksikologicheskii analiz lekarstvennykh veschestv v krovi (plazme, syvorotke) metodom vysokoeffektivnoi zhidkostnoi khromatografii. Perspektivy razvitiia i sovershenstvovaniia sudebno-meditsinskoi nauki i praktiki. Tiumen, 316.

16. Melentev, A. B. (2002). Skrining lekarstvennykh, narkoticheskikh veschestv i ikh metabolitov metodom gazovoi khromatografii s mass-selektivnym detektorom. Problemy ekspertizy v meditsine, 2 (4), 15-20.

17. Derzhavna Farmakopeia Ukrainy (2004). DP «Naukovo-ekspertnyi farmakopeinyi tsentr». Kharkiv: RIREH, 520.

18. Clarke, E. J. C. (2011). Isolation and Identification of Drugs in Pharmaceuticals, Body Fluids and Postmortem Materia. London: The Pharm. Press, 2463.

19. Tomarovskaya, T. O., Mamina, O. O., Kabachny, V. I. (2018). The choice of optimal conditions for chemicaltoxicological analysis of diphenhydramine by the thin-layer chromatography. Science and Society. Hamilton, 194-200.

20. Baram, G. I. (2005). Khromatograf «Milikhrom A-02». Opredelenie veschestv s primeneniem baz dannykh «VEZHKHUF». Novosibirsk: ZAO Institut khromatografii, 64.

21. Mamina, O. O., Kabachny, V. I., Bondarenko, N. Yu. (2019). The determination of dimedrol by the HPLC method. Advances of science. Karlovy Vary - Kyiv, 91-101.

Received date 07.07.2020

Accepted date 29.07.2020

Published date 31.08.2020

Olena Mamina, Doctor of Pharmaceutical Sciences, Professor, Department of Inorganic and Physical Chemistry, National University of Pharmacy, Pushkinska str., 53, Kharkiv, Ukraine, 61002

E-mail: a_mamina@ukr.net

Volodimir Kabachny, Doctor of Pharmaceutical Sciences, Professor, Department of Inorganic and Physical Chemistry, National University of Pharmacy, Pushkinska str., 53, Kharkiv, Ukraine, 61002

E-mail: vikpharm@gmail.com

Tetyana Tomarovska, PhD, Associate Professor, Department of Inorganic and Physical Chemistry ,National University of Pharmacy, Pushkinska str., 53, Kharkiv, Ukraine, 61002

E-mail: tomarovskaya63@gmail.com

Natalya Bondarenko, PhD, Associate Professor, Department of Inorganic and Physical Chemistry, National University of Pharmacy, Pushkinska str., 53, Kharkiv, Ukraine, 61002

E-mail: tropikana@ukr.net 